Acta Technologica Agriculturae 2

Nitra, Slovaca Universitas Agriculturae Nitriae, 2020, pp. 67-72

\title{
INNOVATIVE HUSK-CRETE BUILDING MATERIALS FROM RICE CHAFF AND MODIFIED CEMENT MORTARS
}

\author{
Banjo AKINYEMI ${ }^{1 *}$, Temidayo E. OMONIYI ${ }^{2}$, Olugbenga ELEMILE ${ }^{1}$, Oluwafemi AROWOFILA ${ }^{1}$ \\ ${ }^{1}$ Structures and Environment Unit, Landmark University Omuaran, Kwara, Nigeria \\ ${ }^{2}$ University of Ibadan, Oyo, Nigeria
}

\begin{abstract}
The study considers the use of rice chaffs (husks) as an aggregate in a composite cement matrix system. Cement mortars were modified using styrene butadiene rubber polymer for strengthening. The goal is to develop a lightweight building material with good thermal insulation properties out of agricultural waste. The compressive strength, split tensile strength and flexural strength were experimentally evaluated. Further analyses of the samples were carried out by means of scanning electron microscope and energy dispersive spectroscopy. The key results obtained were presented and analysed with the performance of the proposed husk-crete building material showing adequate properties essential for a lightweight structural material with possible applications for non-structural purposes.
\end{abstract}

Keywords: rice husk; wastes; improvement; particle reinforcement; properties

Presently, there is a global awareness about the need to reduce the utilisation of building materials with high energy consumption because of their ecosystem damaging effects. There have been published detailed reports on their perceived contribution to climate change, greenhouse gas emission increase and devastating effects on the environment (Ürge-Vorsatz and Novikova, 2008). Focus has shifted to the utilization of wastes from agricultural processes on the basis of their environment friendly nature, renewability and recyclability traits (Akinyemi et al., 2019a). Furthermore, materials made of such wastes provide good indoor air quality and thermal comfort for humans; thereby they had become sought-after for different building purposes (Lima et al., 2016). There are numerous studies on utilization of plants or vegetables as reinforcement in both cementitious and non-cementitious applications in order to improve flexural strength; post-crack load resistance capability; impact toughness; increase bending strength; provide good thermal insulation; lower the thermal conductivity; etc. (Mueller, 2004; Sair et al., 2018). Such plants include hemp; bagasse; bamboo; coconut coir; corncob; and rice ashes and husks (Modani and Vyawahare, 2013; Akinyemi and Omoniyi, 2018a, Akinyemi and Omoniyi, 2018b, and Akinyemi et al., 2019b). Worldwide production of rice stands at over 800 million tonnes with majority of it coming from Asia; however, developing nations have lately also increased their production level (Onyango, 2014; Matías, 2019). The husk is a by-product of rice processing and takes up to $20 \%$ of the rice grain total volume. It is usually burnt and used as fuel or sent to landfills where it shows negative impact on the environment (Liu et al., 2013). However, there have been concerted efforts to acknowledge different methods for recycling and reutilization of these wastes through their gainful inclusion to the building environment, reducing thus their negative impact on the eco-system. Rice husk is frequently utilized as thermal insulator in plastic composites, as well as in lightweight cement-based building materials (Choi et al., 2006; Salas et al., 1986). Numerous studies have already been conducted on the use of rice husk ashes as replacement for cement. Majority of these experiments showed that very low mechanical strengths were obtained using it as an aggregate in the mixture design. The study by Yuzer et al. (2013) showed that the compressive strength varied from 0.7 to $2.5 \mathrm{MPa}$; Chabannes et al. (2014) reported that optimum average compressive strength after 60 days was $0.33 \mathrm{MPa}$. Sutas et al. (2012) reported similar results: compressive strength varied from 0.5 to $5.5 \mathrm{MPa}$. Investigations on other plant materials used as aggregates in concrete showed similar results with low mechanical strength performances: from 0.4 to $1.22 \mathrm{MPa}$ and from 0.26 to $0.80 \mathrm{MPa}$ for wood crete and $0.5 \mathrm{MPa}$ for hemp crete (Aigbomian and Fan, 2014; Arnaud and Gourlay, 2012). These results do not meet the minimal requirements for the materials to be designated as lightweight structural material based on the $\mathrm{ACl}$ classification; therefore, a supplementary supportive structure is required. In majority of aforementioned studies, these weaknesses in mechanical strength were taken into account and potential solutions were proposed; these include surface modification of fibres through alkaline solution; acidic treatment; hot water treatment; coating, dry/wet cycles; mechanical (pulping); thermal treatment (pyrolysis); etc. All these treatments would reduce the lignin, cellulose and hemicellulose in the fibres by disrupting the hydrogen

Contact address: Banjo Akinyemi, Structures and Environment Unit, Landmark University Omuaran, Department of Agricultural and Biosystems Engineering, Kwara, Nigeria, e-mail: bantonbows@gmail.com 
bonds within the internal network (Benyahia et al., 2013). Subsequently, there is an increase in surface roughness of the fibre, which is necessary for proper bonding and strength development at the interface of the fibre-matrix (Prompunjai and Sridach, 2010). It is also feasible to improve the cement mortar through polymer modification, which would result in synchronised action alongside the alkaline treatment of the fibres in order to improve the ultimate strength of the composites. The use of polymer modification has been studied with excellent results reported in terms of enhancement of the mechanical strength of plant fibrereinforced cement mortar and concrete (Yan et al., 2016; Ismail et al., 2008). Therefore, this study attempts to develop a husk-crete, which is a composite building material made of rice chaffs (husks) and polymer modified cement mortars. It is expected to conform to the compressive strength given by the $\mathrm{ACl}$ standard for lightweight structural material and show excellent thermal properties.

\section{Material and methods}

\section{Rice husk waste preparation and treatment}

The rice husk $(\mathrm{RH})$ was sourced from a milling factory in Ekiti State (Nigeria) and dried to $2.5 \%$ moisture content (db) after exposure to the ambient surrounding for one week. The $\mathrm{RH}$ was sieved at $1.5 \mathrm{~mm}$ in order to remove unwanted materials and debris, which could affect the mixture properties. It has an average husk particle ranging from 0.77 to $1.3 \mathrm{~mm}$. It was immersed in the diluted sodium hydroxide solution $(5 \%$ conc.) for 2 hours. The mixture was decanted and washed in tap water to remove the leached-out chemicals and debris. Thereafter, the $\mathrm{RH}$ was dried in a ventilated oven at $50{ }^{\circ} \mathrm{C}$ for 2 hours before it was allowed to cool at the ambient temperature at $23^{\circ} \mathrm{C}$.

\section{Cement and polymer additives}

Type 1 Portland cement by Dangote Cement Ltd was used. The styrene butadiene rubber (SBR) polymer emulsion with $50 \%$ solid polymer content; $\mathrm{pH}$ of 9.2 ; and viscosity of 38-159 $\mathrm{mPa} \cdot \mathrm{s}^{-1}$ (supplied by Advanced Concrete Technologies Ltd) was used to modify the cement mortar.

\section{Mixture proportion and husk-crete sample preparation}

Required quantities of cement and sand with ratio of $1: 3$ were measured and mixed thoroughly for approx. 3 minutes.
The $\mathrm{RH}$ volume varied (1 and $1.5 \%$ of the aggregates) while the SBR polymer of 10 and $15 \%(w / w)$ was used to modify the mixture (Table 1). The control sample (mixture A) contained $1.5 \%$ of $\mathrm{RH}$ on the basis of previous investigation (Banjo and Micheal, 2016) and was used for comparison purposes. Half of the necessary water was used to dilute the SBR emulsion for proper mixing with the aggregates and mixing was being performed manually for 2 minutes until homogenous colour and appearance were attained. Thereafter, the remaining water was blended together with the rest of constituents for another 3 minutes in order to produce slurry. Additional water was added until the desired slurry consistency was achieved. The mortar was cast in two types of moulds with dimensions $200 \times 50 \times 5 \mathrm{~mm}$ and $50 \times$ $150 \mathrm{~mm}$ for mechanical tests.

\section{Test methods}

Flexural strength was observed by testing six specimens with dimensions $200 \mathrm{~mm}$ (length) $\times 50 \mathrm{~mm}$ (breadth) $\times$ $5 \mathrm{~mm}$ (width) after curing in water for 7, 14 and 28 days at a loading rate of $1.5 \mathrm{~mm} \cdot \mathrm{min}^{-1}$ in compliance with the ASTM D1037 (2012) standard. Split tensile tests were conducted by testing six cylindrical samples according to the BS EN 12390-6 (2009) at a loading rate of $1.2 \mathrm{kN} \cdot \mathrm{secs}^{-1}$ after similar curing ages. The compressive strength was calculated on the basis of relationship between split tensile strength and compressive strength as shown in Eq. 1:

$$
F_{t}=0.3\left(F_{c}\right) \frac{2}{3}(\mathrm{MPa})
$$

where:

$F_{t} \quad$ - split tensile strength

$F_{c}$ - compressive strength

SEM and EDS analyses were performed using Jeol-7600F equipment for micrograph observation, as well as elemental compositions of the fractured samples.

\section{Results and discussion}

\section{Compressive strength}

As expected, the compressive strength of control sample (mixture $\mathrm{A}$ at $1.5 \% \mathrm{RH}$ ) showed the worst performance. Generally, the observed trend in the husk-crete was that, at

Table 1 Experimental mixture design for husk-crete

\begin{tabular}{|l||c|c|c|c|}
\hline \multicolumn{1}{|c||}{ Components } & \multicolumn{4}{c|}{ Mixture design } \\
\cline { 2 - 5 } & A & B & C & D \\
\hline \hline Cement & 3 & 3 & 3 & 3 \\
\hline Sand & 9 & 9 & 9 & 9 \\
\hline Treated RH & $0.14^{\mathrm{c}}$ & $0.10^{\mathrm{a}}$ & $0.10^{\mathrm{a}}$ & $0.14^{\mathrm{a}}$ \\
\hline SBR polymer & - & $0.30^{\mathrm{b}}$ & $0.45^{\mathrm{b}}$ & $0.14^{\mathrm{a}}$ \\
\hline Water:cement & $0.40^{\mathrm{d}}$ & $0.35^{\mathrm{d}}$ & $0.30^{\mathrm{d}}$ & $0.30^{\mathrm{b}}$ \\
\hline
\end{tabular}

$\mathrm{a}$ - weight of treated RH (kg), b - weight of $0.3 \%$ SBR polymer $(\mathrm{kg}), \mathrm{c}-1.5 \% \mathrm{RH}$ was used as control (kg), $\mathrm{d}-\mathrm{water}$ to cement ratios (ml) 
Table 2 ACl classification of lightweight concrete (Sari and Pasamehmetoglu, 2005)

\begin{tabular}{|l|c|c|c|}
\hline \multirow{2}{*}{ Properties } & \multicolumn{3}{|c|}{ Lightweight concrete classifications } \\
\cline { 2 - 4 } & low & moderate & structural \\
\hline Unit weight $\left(\mathbf{k g} \cdot \mathbf{m}^{-\mathbf{3}}\right.$ ) & $<1,000$ & $1,000-1,500$ & $1,500-2,000$ \\
\hline Compressive strength $(\mathbf{M P a})$ & $0.70-2.00$ & $2.00-15.00$ & $16.00-42.00$ \\
\hline
\end{tabular}

any given fibre content, there was an incremental increase in compressive strength in the polymer dosage, e.g. in mixtures $\mathrm{B}$ and $\mathrm{C}$ with $1 \% \mathrm{RH}$ aggregate and varying 10 and $15 \%$ SBR contents, there were increases in strength of 11,12 and $9 \%$ after 7, 14 and 28 days, respectively. Furthermore, comparing mixtures $D$ and $E$, increases of 7,8 and $15 \%$ in compressive strength at $1.5 \% \mathrm{RH}$ aggregate inclusion and varied SBR proportions were observed. The mechanism responsible for this improvement is the latex films within the SBR polymer, which develop into a polymeric arrangement in the internal structure of the cement composite. It also transformed the transition zone at the interface between the $\mathrm{RH}$ and the cement particles, which resulted in the improved compressive strength (Shadmani et al., 2018). The abundant presence of latex in the spaces within workability and compressive strength of the concrete composites. However, the effects of increasing $\mathrm{RH}$ content on the husk-crete material showed a decline in the compressive strength as reductions in the values were recorded across the curing regimes. In contrast to mixture $\mathrm{B}$, at $10 \%$ SBR the microstructure caused improved

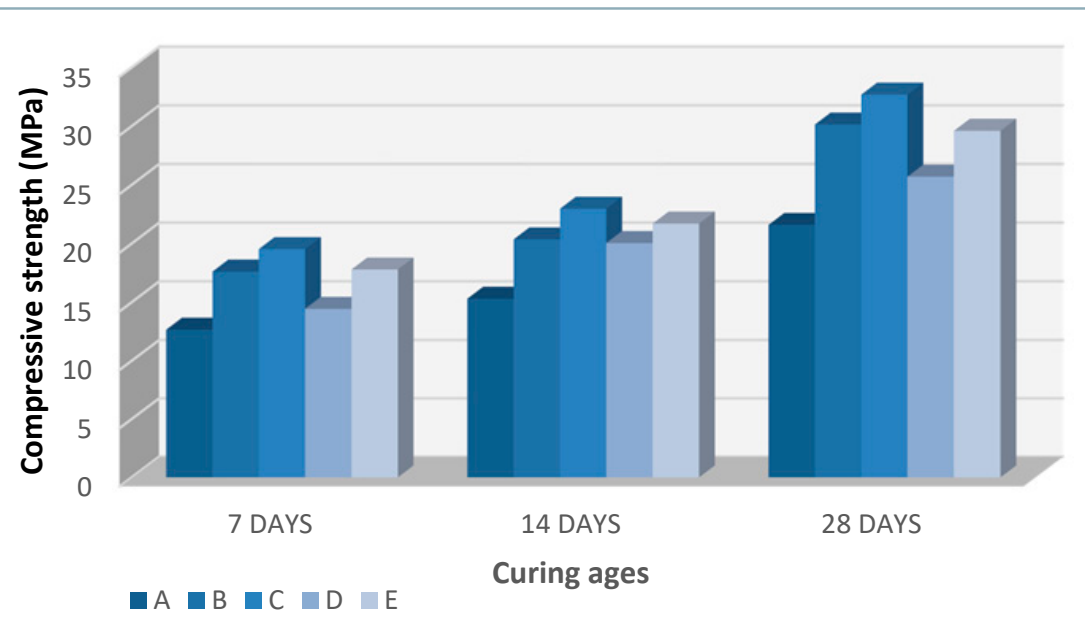

Fig. 1 Compressive strength of husk-crete material

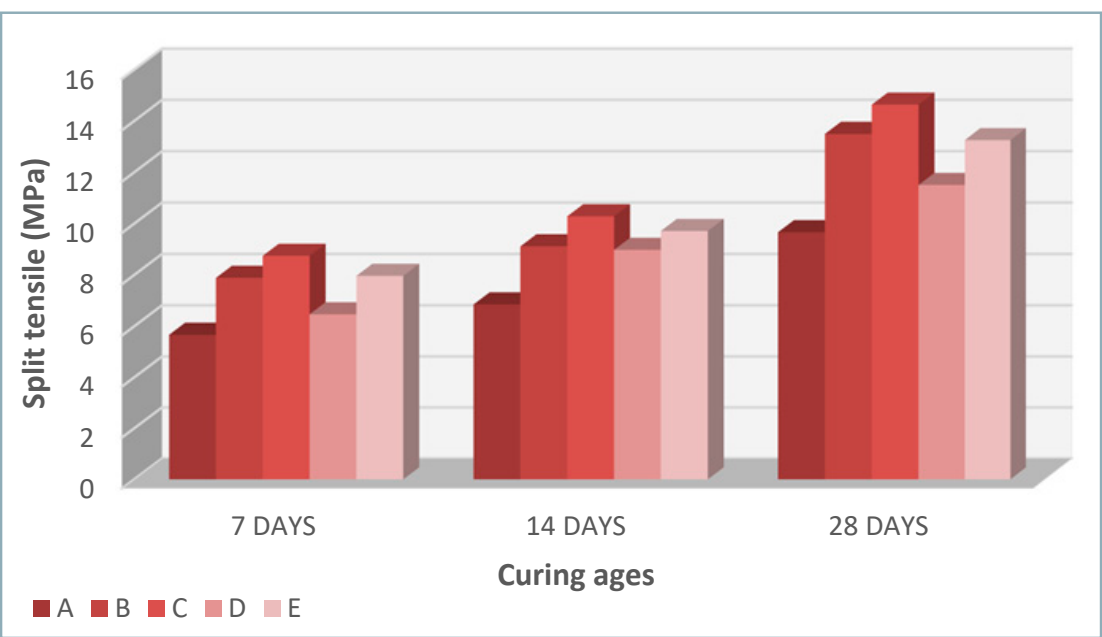

Fig. 2 Split tensile strength of husk-crete material dosage and 1 and $1.5 \%$ RH quantities, reductions of $22,1.5$ and $17 \%$ for mixture $D$ after the curing ages were observed. A similar trend of reduction in the compressive strength with the $\mathrm{RH}$ aggregate increase from 1 to $1.5 \%$ at a given $15 \%$ SBR inclusion across the curing periods was observed as well. This showed that the porosity increased with increment in the rice husk content, which was accompanied by low strength performance of the husk-crete (Chabannes et al., 2015). The compressive strength of the husk-crete material depends on either the physical or chemical bonds, or combination of both bonds between the rice husk particles and cement. The chemical linkage is based on the interactions between the hydrogen bonds, which may form between husk particles, or possibly between the cement matrix and the husk particles. Physical connection can take place during the cement hydration phase, when $\mathrm{C}-\mathrm{S}-\mathrm{H}$ gels and other crystals are developed, interconnecting each with the rest (Pehanich et al., 2004). According to the $\mathrm{ACl}$ classification of lightweight concrete, the husk-crete material can be classified under category 3 as a lightweight structural material, since its compressive strength was within the specified minimum range of $16 \mathrm{MPa}$ (Table 2 ).

\section{Split tensile strength}

The split tensile strength of the huskcretematerial is shown in Fig.2. A similar trend was observed in compressive strength, with strength improving by addition of both rice husk particles and polymers into the mixture. All samples showed better performance than the reference mixture in terms of the resistance to splitting forces. Considering the mixtures with $1 \%$ fibre content at varying polymer contents, the optimal split resistance was obtained at $14.64 \mathrm{MPa}$ for sample $\mathrm{C}$ after 28 days. In the same vein, with $1.5 \%$ fibre inclusion and 10 and 15\% polymer contents, mixture $E$ showed 


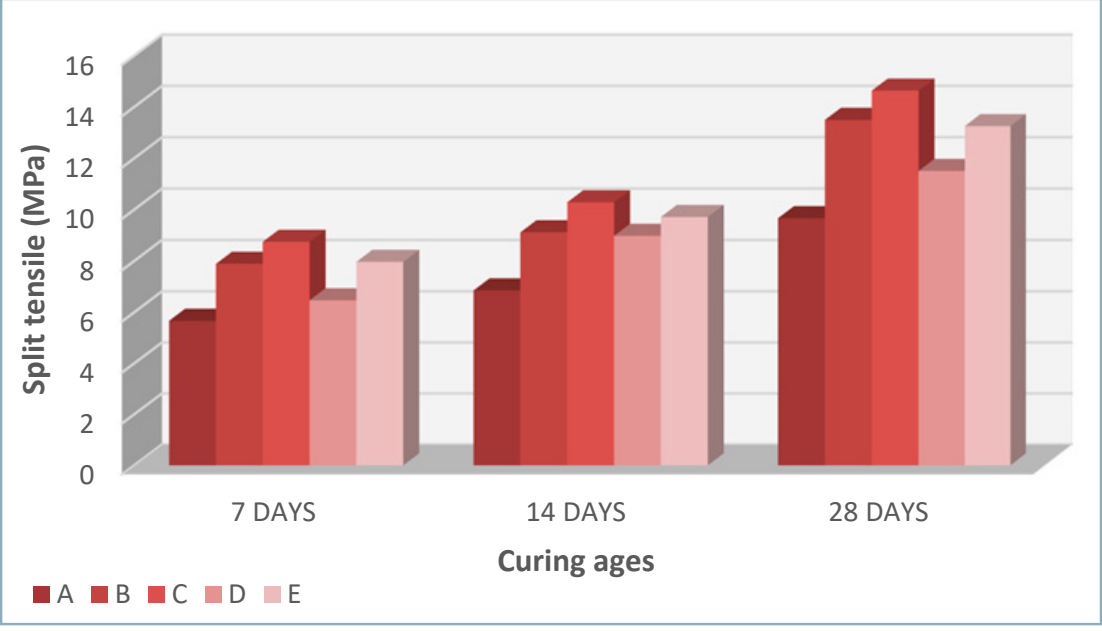

Fig. 3 Flexural strength performance of husk-brick samples

optimal split resistance of $13.26 \mathrm{MPa}$ after 28 days of curing. This implies that the maximum rice husk content as an aggregate is $1 \%$, a decrease in split strength takes place after exceeding this amount. However, it is noticeable that the use of SBR polymer in modification of the cement matrix led to significant enhancement of the husk-crete resistance to splitting forces. It was observed that the material showed higher resistance to tensile forces than polymer mortars because of its improved strength. This is thanks to an improved microstructure formed during the interaction and inter-connection between the cement hydration products and latex (Huang et al., 2010).

\section{Flexural strength}

Flexural strength performance of the husk-crete material is shown in Fig. 3.
It is obvious that inclusion of rice husk particles improved its flexural strength. Optimal resistance to bending was obtained in the mixture consisting of $1.5 \%$ husk particles coupled with the higher dose of SBR polymer with aging of 28 days. Similarly, an increase in flexural performance of earthen material stabilised with plant fibres varying at 2.5 and $5 \%(w / w)$ was reported by Villamizar et al. (2012). To support this observation as well, investigation on flexural strength of earthen material reinforced by vegetable fibre (Millogo et al., 2014) proved that, for each increase in fibre content, a resultant increase in flexural strength would take place until the optimal fibre content would be reached. Thereafter, a decline in the bending strength performance would take place. Consequently, the flexural performance results of this study are in line with previous investigations indicating that, in majority of cases, an increase in flexural strength should be expected when reinforcing the material with plant-based aggregates. It is also necessary to emphasize that it is possible that the bond between the cement hydration products coupled with the SBR polymer latex films can be more efficient in terms of bonding with external convex structure of the rice husk particle. The flexural strength performance could also be influenced by the mechanical inter-connectivity mechanism, in which the cement matrix flows in its liquid form into the cell lumens and pores on the roughened surface of the fibre (due to alkaline treatment). Thereafter, it crystallized to develop into cement plugs, which eventually improved the strength by interlocking the fibre and matrix together (Nozahic et al., 2012).

\section{Scanning electron microscope (SEM) and energy dispersive spectroscopy (EDS) analysis}

SEM micrographs of selected mixtures made of the husk-crete material are shown in Fig. $4(\mathrm{a}-\mathrm{c})$. The reference mixture (sample A) showed a good distribution of conical projections of the rice husk particles at regular intervals on the surface of composites. It is possible to observe abundant presence of pores and voids on the surface (Fig. 4c) with a higher magnification. These were responsible for the weak strength shown by this mixture during the mechanical tests. Compact interfaces free of pores due

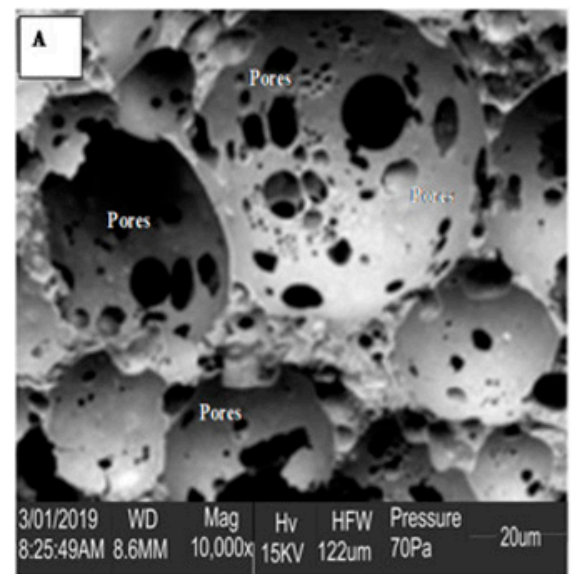

(a) mixture $A(\times 10,000)$

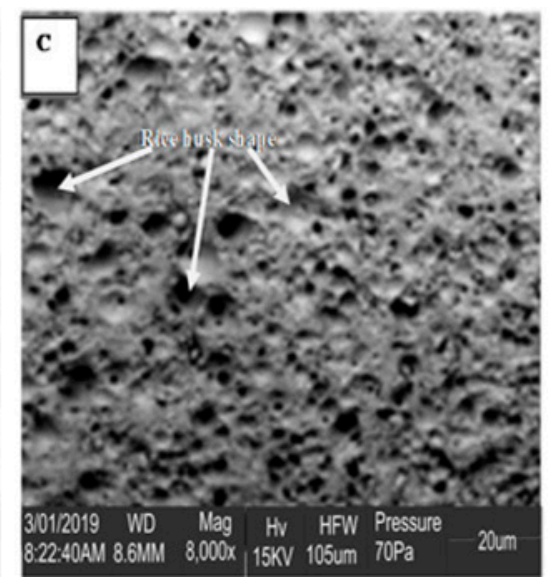

(b) mixture $C(\times 10,000)$

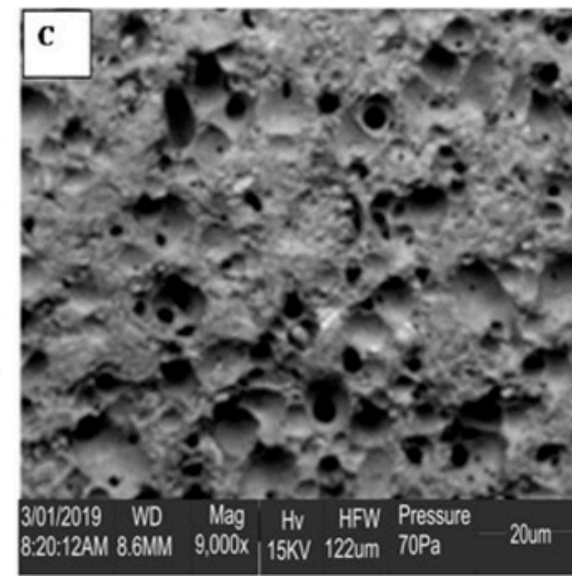

(c) mixture $C(\times 9,000)$

Fig. 3 SEM micrograph of husk-crete lightweight material 
Table 3 Elemental analysis of samples

\begin{tabular}{|l||c|c|c|c|c|c|}
\hline \multicolumn{1}{|c|}{} & \multicolumn{7}{c|}{ Elements (\%) } & Si & Mg \\
\cline { 2 - 8 } & C & $\mathbf{O}$ & Fe & Ca & 4.40 & 1.44 \\
\hline Mixture C & 4.10 & 36.33 & 4.25 & 45.25 & 11.55 & 1.20 \\
\hline Mixture A & 5.50 & 35.30 & 6.10 & 40.20 & \\
\hline
\end{tabular}

to the filling of the voids on the fibre-matrix interface with the reaction of the cement hydrate products and latex film polymers was observed for sample C. EDS analysis was conducted on selected regions of the samples tested and the results are displayed in Table 3. All samples consisted of silicon; carbon; calcium; oxygen; and iron with traces of magnesium. It is, however, clear that sodium was not discovered in any of the samples; this attests to the efficacy of the alkaline treatment of $\mathrm{RH}$ in removing it. The $\mathrm{Ca} / \mathrm{Si}$ ratios were also responsible for the formation of calcium silicate hydrate $(\mathrm{C}-\mathrm{S}-\mathrm{H})$ at the composite surface. The SBR polymer emulsion also improved the fibre-pozzolan bonding situations, aided the pozzolanic chemical reactions and boosted the process of cement hydration (Plank and Gretz, 2008).

\section{Conclusions}

The study presented outlined the utilization possibilities of rice chaffs (husks) as an aggregate in developing a lightweight structural building material with good thermal insulation properties. Compressive strength tests showed that increasing of rice husk content in the husk-crete material resulted in a decline across the curing regimes. However, increasing the dosage of the SBR improved the resistance of the husk-crete material to compressive forces. Flexural strength performance results indicated improvements in strength as the proportion of the husk aggregates increased. It is also interesting to note that this strength is possibly caused by the bond between the cement hydration products coupled with the SBR polymer latex films having more effectiveness in bonding with the external convex structure of the rice husk particle. With the help of SEM/EDS, the study was able to show that treatment of rice husk with alkali chemicals and use of polymer additive for strengthening the cement mortar assisted in improving the bond at the interface between the husk particles and the cement matrix. Therefore, its use can be recommended for the purposes of reinforcement in development of lightweight building materials. Further studies on the durability of such materials under various environmental conditions should be carried out as well.

\section{References}

AIGBOMIAN, E. P. - FAN, M. 2014. Development of wood-crete from treated sawdust. In Construction and Building Materials, vol. 52, pp. 353-360.

AKINYEMI, B. A. - OMONIYI,T.E. 2018a. Effect of moisture on thermal properties of acrylic polymer modified mortar reinforced with alkali treated bamboo fibres. In Journal of the Indian Academy of Wood Science, vol. 15, no. 1, pp. 45-51.
AKINYEMI, B. - OMONIYI, T. 2018b. Properties of latex polymer modified mortars reinforced with waste bamboo fibers from construction waste. In Buildings, vol. 8, no. 11, pp. 149.

AKINYEMI, B.A. - OKONKWO, C.E. - ALHASSAN, E.A. - AJIBOYE M. 2019a. Durability and strength properties of particle boards from polystyrene-wood wastes. Journal of Material Cycles and Waste Management. https://doi.org/10.1007/s10163-019-00905-6

AKINYEMI, B. A. - BAMIDELE, A. - JOEL, E. 2019b. Response of coir fibre reinforced cement composites to water repellent chemical additive and microwave accelerated curing. In Cellulose, vol. 26, no. 8, pp. 4987-4999.

ARNAUD, L. - GOURLAY, E. 2012. Experimental study of parameters influencing mechanical properties of hemp concretes. In Construction and Building Materials, vol. 28, no. 1, pp. 50-56.

ASTM D1037. 2012. Standard test methods for evaluating properties of wood-base fibre and particle panel materials.

BANJO, A. - MICHEAL, O. 2016. Prospects of coir fibre as reinforcement in termite mound clay material. In Acta Technologica Agriculturae, vol. 19, no. 3, pp. 57-62.

BENYAHIA, A. - MERROUCHE, A. - ROKBI, M. - KOUADRI, Z. 2013. Study of the alkali treatment effect on the mechanical behavior of the composite unsaturated polyester-Alfa fibers. In Mechanics and Industry, vol. 15, no. 1, pp. 69-73.

BRITISH STANDARDS INSTITUTE. 2009. BS EN 12390-6: 2009. Testing hardened concrete Part 6: Tensile splitting strength of test specimens.

CHABANNES, M. - BÉNÉZET, J. C. - CLERC, L. - GARCIA-DIAZ, E. 2014. Use of raw rice husk as natural aggregate in a lightweight insulating concrete: An innovative application. In Construction and Building Materials, vol. 70, pp. 428-438.

CHABANNES, M. - GARCIA-DIAZ, E. - CLERC, L. - BÉNÉZET, J. C. 2015. Studying the hardening and mechanical performances of rice husk and hemp-based building materials cured under natural and accelerated carbonation. In Construction and Building Materials, vol. 94, pp. 105-115.

CHOI, N. W. - MORI, I. - OHAMA, Y. 2006. Development of rice husks-plastics composites for building materials. In Waste Management, vol. 26, no. 2, pp. 189-194.

HUANG, B. - WU, H. - SHU, X. - BURDETTE, E. G. 2010. Laboratory evaluation of permeability and strength of polymer-modified pervious concrete. In Construction and Building Materials vol. 24, pp. 818-823.

ISMAIL, M. R. - YOUSSEF, H. A. - ALI, M. A. - ZAHRAN, A. H. - AFIFI, M. S. 2008. Utilization of emulsion polymer for preparing bagasse fibers polymer-cement composites. In Journal of Applied Polymer Science, vol. 107, no. 3, pp. 1900-1910.

LIMA, J. - FARIA, P. - SANTOS SILVA, A. 2016. Earthen plasters based on illitic soils from Barrocal region of Algarve: contributions for building performance and sustainability. In Key Engineering Materials, vol. 678, pp. 64-77.

LIU, N. - HUO, K. - McDOWELL, M. T. - ZHAO, J. - CUI, Y. 2013. Rice husks as a sustainable source of nanostructured silicon for high performance Li-ion battery anodes. In Scientific Reports, vol. 3.

MATÍAS, J. - CRUZ, V. - GARCÍA, A. - GONZÁLEZ, D. 2019. Evaluation of rice straw yield, fibre composition and collection under 
Mediterranean conditions. In Acta Technologica Agriculturae, vol. 22 , no. 2 , pp. $43-47$.

MILLOGO, Y. - MOREL, J. C. - AUBERT, J. E. - GHAVAMI, K. 2014. Experimental analysis of Pressed Adobe Blocks reinforced with Hibiscus cannabinus fibers. In Construction and Building Materials, vol. 52, pp. 71-78.

MODANI, P. O. - VYAWAHARE, M. R. 2013. Utilization of bagasse ash as a partial replacement of fine aggregate in concrete. In Procedia Engineering, vol. 51, pp. 25-29.

MUELLER, D. H. 2004. Improving the impact strength of natural fiber reinforced composites by specifically designed material and process parameters. In International Nonwovens Journal, vol. 4, pp. 15589250040 os- 1300405.

NOZAHIC, V. - AMZIANE, S. - TORRENT, G. - SAIIDI, K. - DE BAYNAST, H. 2012. Design of green concrete made of plant-derived aggregates and a pumice-lime binder. In Cement and Concrete Composites, vol. 34, no. 2, pp. 231-241.

ONYANGO, A. O. 2014. Exploring options for improving rice production to reduce hunger and poverty in Kenya. In World Environment, vol. 4, no. 4, pp. 172-179.

PEHANICH, J. L. - BLANKENHORN, P. R. - SILSBEE, M. R. 2004 Wood fiber surface treatment level effects on selected mechanical properties of wood fiber-cement composites. In Cement and Concrete Research, vol. 34, no. 1, pp. 59-65.

PLANK, J. - GRETZ, M. 2008. Study on the interaction between anionic and cationic latex particles and Portland cement. In Colloids and Surfaces A: Physicochemical and Engineering Aspects, vol. 330, no. 2-3, pp. 227-233.

PROMPUNJAI, A. - SRIDACH, W. 2010. Preparation and some mechanical properties of composite materials made from sawdust, cassava starch and natural rubber latex. In International Journal of Materials and Metallurgical Engineering, vol. 4, no. 12, pp. 773-776. SAIR, S. - OUSHABI, A. - KAMMOUNI, A. - TANANE, O. - ABBOUD, Y. - EL BOUARI, A. 2018. Mechanical and thermal conductivity properties of hemp fiber reinforced polyurethane composites. In Case Studies in Construction Materials, vol. 8, pp. 203-212.
SALAS, J. - ALVAREZ, M. - VERAS, J. 1986. Lightweight insulating concretes with rice husk. In International Journal of Cement Composites and Lightweight Concrete, vol. 8, no. 3, pp. 171-180.

SARI, D. - PASAMEHMETOGLU, A. G. 2005. The effects of gradation and admixture on the pumice lightweight aggregate concrete. In Cement and Concrete Research, vol. 35, no. 5, pp. 936-942.

SHADMANI, A. - TAHMOURESI, B. - SARADAR, A. - MOHSENI, E. 2018. Durability and microstructure properties of SBR-modified concrete containing recycled asphalt pavement. In Construction and Building Materials, vol. 185, pp. 380-390.

SUTAS, J. - MANA, A. - PITAK, L. 2012. Effect of rice husk and rice husk ash to properties of material. In Procedia Engineering, vol. 32, pp. 1061-1067.

ÜRGE-VORSATZ, D. - NOVIKOVA, A. 2008. Potentials and costs of carbon dioxide mitigation in the world's buildings. In Energy Policy, vol. 36, no. 2, pp. 642-661.

VILLAMIZAR, M. C. N. - ARAQUE, V. S. - REYES, C. A. R. - SILVA, R. S. 2012. Effect of the addition of coal-ash and cassava peels on the engineering properties of compressed earth blocks. In Construction and Building Materials, vol. 36, pp. 276-286.

YAN, L. - CHOUW, N. - HUANG, L. - KASAL, B. 2016. Effect of alkali treatment on microstructure and mechanical properties of coir fibres, coir fibre reinforced-polymer composites and reinforced-cementitious composites. In Construction and Building Materials, vol. 112, pp. 168-182.

YUZER, N. - CINAR, Z. - AKOZ, F.- BIRICIK, H. - GURKAN, Y. Y. - KABAY, N. - KIZILKANAT, A. B. 2013. Influence of raw rice husk addition on structure and properties of concrete. In Construction and Building Materials, vol. 44, pp. 54-62. 